\title{
Fra Roko Romac, dušobrižnik Hrvata u Australiji 1955.-1970.
}

\author{
Ante Kožul*
}

\begin{abstract}
Sažetak
Autor je na temelju arhivskoga gradiva, novinskih članaka i literature istražio život i djelovanje fra Roka Romca u Australiji. Fra Roko Romac rođen je kao Stjepan Tot, a od ređenja 1930. do prosinca 1947. djelovao pod redovničkim imenom Osvald Toth. Ime Roko Romac uzeo je zbog sigurnosnih razloga pod pritiskom djelovanja jugoslavenskih tajnih službi u međunarodnoj zajednici. $U$ Australiju je došao 1955. te preuzeo brigu o Hrvatima u Adelaideu i Perthu. Najveći je trag ostavio među sydneyskim Hrvatima, gdje je djelovao od 1957. sve do smrti 1970. godine. Pokrenuo je i uređivao novine Dom, prvi vjerski mjesečnik Hrvata u Australiji. Inicirao je kupnju prve hrvatske katoličke crkve u Australiji posvećene sv. Antunu Padovanskomu. Začetnik je ideje o gradnji škole i svetišta u Tumbi Umbi kraj Goshforda.
\end{abstract}

Ključne riječi: Roko Romac; Osvald Toth; Stjepan Tot; novine Dom; hrvatski iseljenici; Hrvatski katolički centar Summer Hill; Tumbi Umbi

\section{Uvod}

Jasno izražen nacionalni identitet i snažni kršćanski osjećaji važno su obilježje hrvatskih iseljeničkih zajednica diljem svijeta. Fra Roko Romac svojim je djelovanjem među australskim Hrvatima uvelike doprinio očuvanju kršćanskoga duha i hrvatskih nacionalnih vrijednosti. Kako bi što bolje upoznao hrvatske iseljenike, uveo je blagoslov kuća, ulazio je u njihove domove i upoznavao je hrvatske obitelji, uvijek je bio spreman na razgovor i druženje. Organizirao je brojna hodočašća, tečajeve pripreme za mladence, pozivao je na ispovijed duše i život u čistoći. Uz pastoralnu skrb neumorno je djelovao i na socijalnom području, posebice vodeći brigu o novopridošlim iseljenicima, kojima je pomagao u traženju smještaja i posla i rješavanju administrativnih prepreka pri australskim vlastima.

* Ante Kožul, doktorand, Odsjek za povijest, Fakultet hrvatskih studija Sveučilišta u Zagrebu. Adresa: Borongajska cesta 83d, 10000 Zagreb, Hrvatska. ORCID iD: https://orcid.org/0000 0002-9525-5625. E-adresa: antekozul@gmail.com 
Svojom je neizmjernom energijom i voljom pokretao mnoge projekte, naglašavajući pritom važnost doma i obitelji, mnogo vremena posvećujući odgoju i obrazovanju mladih. U štovanju Majke Božje isticao je povezanost iseljene Hrvatske s Domovinom, a obilazak marijanskih svetišta u Europi pružio mu je potreban mir i snagu u vrijeme jugoslavenskih optužbi iznesenih pred australskom javnosti i vlastima. Uzor u progonjenom kardinalu Stepincu davao mu je vjeru i ustrajnost da i sam izdrži napade jugoslavenskih vlasti, koje su ga neosnovano progonile i u Domovini i u iseljeništvu. Vlastito crkveno djelovanje i vjerski život nastojao je odijeliti od privrženosti pojedinim hrvatskim iseljeničkim političkim strankama i organizacijama, istovremeno jasno izražavajući ljubav prema Domovini i potrebu stvaranja samostalne i neovisne hrvatske države. Ostavština plodova rada fra Roka Romca i danas je vrijedno vrelo snage i vjere u očuvanju kršćanskoga načina života i hrvatskoga nacionalnoga identiteta među generacijama iseljenika Hrvata u Australiji.

\section{1. Školovanje i svećeništvo u Hrvatskoj}

Stjepan Tot rođen je 3. prosinca 1905. u Petrijanecu kraj Varaždina. Sin je Josipa i Lujze rođene Debeljak. Još od rane mladosti želio je biti svećenik te je ušao u franjevačko sjemenište u Varaždinu. Studirao je na sveučilištu u Zagrebu, a od 1927. do 1930. pohađao je Franjevačko sveučilište u Paderbornu u Njemačkoj pod vodstvom fra Aleksa Benigera. Za svećenika je zaređen 5. travnja 1930. u Paderbornu. Prilikom ulaska u franjevački red uzeo je ime Osvald, a slovo $h$ prezimenu Tot dodano je od strane Vatikanskoga vijeća omaškom radi lakšega izgovora, ${ }^{1}$ pa se je od tada služio imenom Osvald Toth. Odmah po zaređenju vratio se je u rodni kraj na mjesto nastavnika u Franjevačkoj gimnaziji u Varaždinu, a podučavao je i u srednjoj školi u Našicama i gimnaziji u Bjelovaru. Za vrijeme njegova svećeništva, u Bjelovaru je 1935. izgrađen samostan i crkva svetoga Ante Padovanskoga. Djelovao je i u bjelovarskoj bolnici, a danas jedna ulica u Bjelovaru nosi njegovo ime. U Viroviticu je došao 1937., gdje se je zadržao godinu dana, a o razlozima povlačenja iz Virovitice odgovore je tražio u Beogradu, gdje mu je rečeno da je njegovo organiziranje crkvenih zborova protivno stavovima vlade. Kratko je boravio na Trsatu, odakle je otišao 1939., nakon čega je dvije godine predavao u ženskoj gimnaziji u Savskoj cesti u Zagrebu. ${ }^{2}$

Godine 1941. nadbiskup Alojzije Stepinac tražio je dobrovoljce za popunjavanje upražnjenih svećeničkih mjesta, pa je Osvald Toth otišao u Gvozdansko, gdje je hrvatska katolička populacija od oko 300 stanovnika bila znatno manja od brojnije pravoslavne, najvećim dijelom srpske etničke zajednice. Tijekom početnih godina rata došao je u nemilost Titovih partizana zbog opiranja njihovim idejama svojim djelovanjem u školstvu i vodeći brigu jednako i o katoličkoj i o

1 AU-NAA-A6937-PP/13. Romac, Stephan Roch, 1961-1986, str. 43.

2 AU-NAA-A6119-2798. Roch Stephan Romac-Volume 1, 1964-1967, str. 126. 
pravoslavnoj zajednici. U prosincu 1941. partizanske snage ušle su u Gvozdansko, a lokalno pravoslavno stanovništvo uvjerilo ih je da Toth nije suradnik ustaškoga režima te je on ostao u selu. Unatoč obećanju osobne sigurnosti, partizani su 26. prosinca 1941. u osvetničkom pohodu razrušili katoličku crkvu te oskvrnuli svećeničko ruho i svete knjige. Toth je istoga dana sa skupinom djece neuspješno pokušao pobjeći iz sela, a već sljedeće večeri partizani su ga u dva navrata pokušali ubiti. Toth je pobjegao iz Gvozdanskoga u obližnji Žirovac, gdje je do travnja 1942. pomagao pri liječenju ranjenih civila u improviziranoj bolnici smještenoj u lokalnoj školi. U Gvozdansko se vratio na vijest da su partizani protjerani prema jugu. Oko 9. travnja vlasti Nezavisne Države Hrvatske na Gvozdansko su iz aviona bacile letke kojima su pozvale hrvatsko stanovništvo da napusti selo jer će biti bombardirano ako ga ne napuste partizani. Toth je pozvao svo stanovništvo da ostane u svojim kućama. Pravoslavno stanovništvo zamolilo je Totha da posjeti hrvatsko zapovjedništvo u Dvoru na Uni kako bi ih obavijestio da su partizani napustili selo te kako je preostalo jedino lokalno stanovništvo. Sljedećeg jutra Toth je u pratnji devet stanovnika Gvozdanskoga otišao u Dvor na Uni i objasnio da su partizani napustili selo te kako je preostalo jedino lokalno stanovništvo. Nakon razgovora s ustaškim predstavnicima Tothu je rečeno da se njegova pratnja može vratiti u Gvozdansko. Sljedećega jutra stanovnica Dvora na Uni obavijestila je Totha kako su sva devetorica iz njegove pratnje prilikom povratka u selo uhićeni i pogubljeni od strane partizana te kako je i sam osuđen na smrt. Toth je shvatio kako u Gvozdanskom nije siguran te je 11. travnja 1942. napustio Dvor na Uni i otišao kod rođaka u Zagreb. ${ }^{3}$

\section{Svećeništvo u iseljeništvu}

Krajem 1942. u Hrvatsku je iz Njemačke došao Mate Luketa, ${ }^{4}$ svećenik šibenske biskupije, i od nadbiskupa Stepinca zamolio pomoć pri vjerskoj skrbi za približno 16.000 Hrvata na prisilnom radu u Njemačkoj. S obzirom na to da su partizani u više navrata pokušali zatočiti Totha, nadbiskup Stepinac uputio ga je u Njemačku, gdje je brinuo o Hrvatima na prisilnom radu. Toth je u Hannover došao u jesen 1942. i ostao sve do 1944., kada je premješten u Koblenz na Rajni, gdje je ostao do kraja rata. Iz Njemačke je otišao u Italiju, prvo u izbjeglički kamp Modena, a 1946. u kamp Bagnoli blizu Napulja, gdje je ostao do svibnja 1947. godine. Tijekom boravka u kampu u Italiji Toth je po nalogu britanskih vlasti, koje su završetkom rata bile u potrazi za bivšim članovima ustaške vlade, bio zatočen u zatvoru Regina Elena u Rimu. U navedenom slučaju Osvald Toth zamijenjen je s Dragutinom Tothom, ministrom obrta, veleobrta i trgovine u vladi NDH. ${ }^{5}$

3 AU-NAA-A6119-2798. Roch Stephan Romac - Volume 1, 1964-1967, str. 122-126.

4 Mate Luketa rođen je u Primoštenu 21. veljače 1911. godine. Za vrijeme Drugoga svjetskoga rata svećeništvo je služio u Njemačkoj, odakle je 1946. otišao u Argentinu. Umro je u Buenos Airesu 3. svibnja 1977. (Čovo, 2019, 41-42).

5 AU-NAA-A6119-2798. Roch Stephan Romac - Volume 1, 1964-1967, str. 125. 
Istovremeno su jugoslavenske vlasti prema vlastitim popisima tragale za osobama koje su proglasili ratnim zločincima. Osobe su svrstane u liste kao kvalificirani ratni zločinci (crna lista), osumnjičeni za ratne zločine (smeđa lista) i osobe koje nisu osuđene (bijela lista). Toth se je nalazio na smeđoj listi. ${ }^{6}$

U listopadu 1947. Toth je premješten iz zatvora Regina Elena u izbjeglički kamp u Riminiju, odakle je pobjegao u Grottamare, gdje je podučavao u lokalnoj školi. U studenom 1947. Toth je otišao u Rim, gdje je stupio u kontakt s fra Petrom Čapkunom i fra Ivanom Juričem. Oni su ga upoznali sa slučajem franjevačkoga svećenika fra Roka Romca, ${ }^{7}$ člana Franjevačke provincije Presvetoga Otkupitelja u Dalmaciji, koji dobivenu vizu za odlazak u Argentinu nije iskoristio, te su Tothu predložili da Romčeve pripremljenije dokumente upotrijebi za odlazak iz Italije. Toth je savjet poslušao i brodom Andrea Gritti 17. ili 18. prosinca 1947. napustio Italiju. Od toga trenutka pa sve do smrti Toth se je u svojem djelovanju služio imenom fra Roko Romac, pa ga i mi u nastavku ovoga rada tako imenujemo. Po dolasku u Argentinu (15. siječnja 1948.) pristao je u Buenos Aires i otišao u Villa Martela, gdje se je već smjestila brojnija hrvatska zajednica. U ožujku 1949. otišao je u Boliviju, gdje je ostao sljedećih šest godina kao svećenik misionar. Nakon Bolivije otišao je u Venezuelu, u vrijeme kada monsinjor Crennin i franjevački provincijal države New South Wales u Australiji izražavaju potrebu za svećenikom koji će brinuti o hrvatskoj zajednici u toj zemlji. Za potrebe izdavanja dozvole za ulazak u Australiju britanskoj ambasadi u Venezueli dostavljena su pisma preporuke od strane voditelja franjevačkoga reda u Jugoslaviji i od vrhovnoga voditelja franjevačkoga reda u Rimu. Na ime fra Romca viza za ulazak u Australiju odobrena je 6. svibnja 1955., a u Brisbane je stigao 31. svibnja 1955.8

\section{Svećeništvo u Australiji}

Svećeničko djelovanje u Australiji Roko Romac započeo je u Adelaideu, gdje je naslijedio Ivana Mihalica, a povremeno je odlazio i u Perth i Milduru. Upravo su fra Romac i Mihalic, uz Marijana Grgasa »dio trolista koji je organizirao prva vjernička okupljališta za Hrvate i postavio temelje dušobrižništvu hrvatskih doseljenika u toj zemlji« (Hoško, 1996, 11). Roko Romac je Mihalica naslijedio i u Sydneyu, u koji je došao 1957. i gdje je ostao djelovati sve do kraja života. Iskustvo djelovanja u iseljeničkim kampovima u Italiji fra Romac prenio je i na australski

7 Fra Roko Romac rođen je u mjestu Glavice kod Sinja 13. ožujka 1915. godine. Nakon završene Franjevačke gimnazije u Sinju 1933. pristupio je Franjevačkoj provinciji Presvetoga Otkupitelja u Zaostrogu. Bio je kapelan u Metkoviću od 1940. do 1944. godine. Napustio je Domovinu pred kraj Drugoga svjetskoga rata i kratko boravio u Italiji (1945.-1947.), odakle je otišao u SAD. Nakon više od dvadeset godina u SAD-u 1970. preuzeo je pastoralnu skrb o hrvatskim iseljenicima u Njemačkoj. Umro je u Frankfurtu 10. prosinca 1988., a pokopan je u rodnom Sinju (Hoško, 1996, 86).

8 AU-NAA-A6119-2798. Roch Stephan Romac - Volume 1, 1964-1967, str. 124-125. 
kontinent. Nakon posjeta kampu Bonegllia 1957., u kojem se je nalazilo oko 200 Hrvata, zatražio je pomoć od hrvatskih društava pri traženju smještaja i zaposlenja, posebice za obitelji s malom djecom (Lovoković, 2010, 61). Pomoć potrebitima nastojao je ostvariti ponovnim pokretanjem Hrvatskoga dobrotvornoga društva. Društvo je osnovano 1952. i bilo je jedno od prvih hrvatskih organizacija u Australiji. Pokrenuto s ciljem da pomogne one najsiromašnije koji pristignu na taj daleki kontinent, društvo je s vremenom gubilo zamah u svojem djelovanju. Fra Romac okupio je »ostatke društva, obnovio ga s mladjim silama, želeći da ne propadne do kraja onaj prvotni žar, koji je pokrenuo prve osnivače, te je naišao na mlade sile, koje su mu pomogle, da je društvo oživilo. Da se obnovilo. Da je počelo djelovati« (Romac, 1959a, 14). Društvo je Roko Romac zamišljao po uzoru na Caritas Zagrebačke nadbiskupije, s željom da »nas vodi duh kardinala i mučenika Stepinca, kojemu je bila Karitas u Zagrebu mila kao zjenica Njegova mučeničkog oka. Slijedimo ga i oživimo ono, što je Njemu bilo najplemenitije u radu; svećeničkom i ljudskom: pomagati bližnjega svoga« (Romac, 1959b, 15).

Svjestan važnosti hrvatskoga jezika i kulture u očuvanju identiteta i povezanosti s Domovinom pokrenuo je osnivanje Hrvatske škole, koja je djelovala u Hrvatskom domu (Buckhingham Street), a s vremenom je postala poznata kao "Rokova škola" (Hoško, 1996, 27).

Dugo je vremena priželjkivao postojanje hrvatske crkve i ureda koji bi bili središnje mjesto u okupljanju hrvatskih vjernika u Australiji. Prilika se je ukazala 1968., kada su tzv. kongregacionisti prodavali staru napuštenu crkvu, koja se je sastojala od manje crkve na koju je kasnije dograđena nova, veća crkva, a imala je i podrumske prostorije te veliku dvoranu za sastanke. Novac potreban za kupnju crkve (40.000 dolara) posudio je od australskih franjevaca, a crkvu je uknjižio u vlasništvo franjevačke provincije sv. Ćirila i Metoda sa sjedištem u Zagrebu. Upisivanjem vlasništva hrvatske crkve u Australiji na ime sjedišta franjevaca u Zagrebu simbolički je stvorena veza hrvatskoga naroda i vjere u iseljeništvu s narodom i vjerom u Domovini. Crkvu posvećenu svetomu Antunu Padovanskomu 15. prosinca 1968. blagoslovio je kardinal Norman Gilroy, sydneyski nadbiskup. U sklopu crkve otvoren je i Hrvatski katolički centar Summer Hill, preko kojega je fra Romac pomogao i osnivanje Doma za samce, koji je pružao skrb novopridošlim hrvatskim iseljenicima (Hoško, 1996, 21).

\section{Dom — prvi vjerski mjesečnik Hrvata u Australiji}

Vođen idejom potrebe stalne prisutnosti vjerskih sadržaja u domovima hrvatskih obitelji u iseljeništvu fra Romac je 1958. pokrenuo tiskanje novina Dom, s podnaslovom Mjesečnik za vjersko-kulturni život Hrvata u Australiji i Oceaniji. Bio je to prvi vjerski mjesečnik Hrvata u Australiji, a vlasnik i izdavač novina bilo je Hrvatsko dušobrižništvo Australije. Fra Romac kao glavni urednik, osim pisanja članaka i uređivanja novina, podnio je i najveći teret u organiziranju tiskanja, distribucije i promocije novina među hrvatskom zajednicom. Novine su tematski bile posvećene obilježavanjima važnijih datuma vjerskoga života pojedinih 
svetaca i blaženika te obilježavanju najvažnijih kršćanskih blagdana. Veliki broj izdanja sadržavao je rubriku Štovanje Marije preko kontinenta, u kojoj je isticana njezina važnost u kršćanskom životu vjernika, kao i velika pažnja i povezanost hrvatskoga naroda u Domovini i svijetu prema Majci Božjoj. Veliko značenje za novine imala je i rubrika Cup-of-tea ćaskanje za mali narod, u kojoj je kroz priče u obliku dijaloga naglašavana potreba sloge, poštivanja, poštenja i suradnje $\mathrm{Hr}$ vata izvan Domovine, na čemu je u svojem svakodnevnom radu upravo fra Romac stalno inzistirao. Smatrao je da se iskreni i pravi vjernik postaje još od malih nogu, stoga je u novinama postojala stranica namijenjena djeci, u kojoj su kroz poučne pričice za djecu ispričane poruke s ciljem pravilnoga odgoja najmlađih. U predstavljanju novina u prvom broju iz lipnja 1958. fra Romac čitateljstvo obavještava da će Dom »donašati vijesti o svim pozitivnim pojavama u našem hrvatskom životu u Australiji, o svemu dobrom i poštenom i plemenitom i korisnom za Hrvate, pa bilo to učinjeno od bilo koje hrvatske jedinice, političke, kulturne ili športske, od bilo kojeg kluba, hrvatskog društva ili političke stranke u Australiji [...] „Dom“ će dakle biti i mora biti ognjište, oko kojega će se sakupljati svi prijatelji gore spomenutih načela, a koje uredništvo najtoplije pozdravlja, kao prave i iskrene prijatelje Hrvatstva u izbjeglištvu « (Romac, 1958, 14).

Novine je fra Romac marljivo vodio i uređivao do 1962., kada je njegov rad nastavio fra Josip Kasić. Novinama je promijenjen naslov u Hrvatski dom, a u uvodniku prvoga broja fra Kasić je pohvalio dotadašnja izdanja ističući kako »I naš skromni list je jedan tihi borac za Vjeru i Dom. Kroz četiri godine kucao je na vrata mnogih hrvatskih obitelji i pojedinaca i unašao vedrinu i nadu u bolje dane za naš napaćeni narod. Dizao je vjerski moral i rodoljubni žar medju australskim Hrvatima [...] Stajao je čvrsto na braniku svih hrvatskih narodnih ideala [...] Na izazove i uvrede nije reagirao. Primao je kršćanskom ljubavlju i pohvale i pokude« (Kasić, 1962, 3). Posebnim riječima fra Kasić zahvalio je fra Romcu, »dosadašnjem uredniku, koji je činio sve poslove od prvog dana. Njemu izričito ide zasluga, što je prvi hrvatski vjersko-kulturni list pokrenut na području Australije. Kroz četiri godine nosio je sav teret uredništva na svojim ledjima i franjevačkom strpljivošću prelazio preko zapreka i poteškoća, koje su često bile ne male [...] Koliko je puta napisao od prvog do zadnjeg slova u pojedinom broju, jer su suradnici spavali. I sada, kada je odložio svoje uredničko pero, da ga zamijeni tlocrtima gradnje Hrvatskog dječjeg doma u Tumbi Umbi i prekrasne crkve, posvećene Kraljici Hrvata [...] molimo Gospodina, da mu dade snage, da dovrši svoje najveće životno djelo na čast hrvatskom rodu i ponos australskih Hrvata« (Kasić, 1962, 3-4).

\section{Projekt doma i crkve u Tumbi Umbi}

Cjelokupni neumorni rad fra Romca, jednako na vjerskom i svjetovnom području života, najbolje ocrtava projekt gradnje hrvatskoga dječjega doma i crkve posvećene Majci Božjoj. Dom je bio predviđen za boravak djece tijekom školskih praznika, u vrijeme kada su njihovi roditelji na poslu, kako bi mlade okupio u 
zajedničkom druženju, korisnom radu i molitvi. U ostatku godine predviđena je organizacija izleta, duhovnih vježbi i priprema za mlade bračne parove. Ideja o gradnji crkve i doma za djecu prvotno je bila predviđena u mjestu Kiama, međutim, kako površina zemljišta nije odgovarala projektu gradnje tri bloka zgrada, kao nova lokacija odabrano je mjesto Tumbi Umbi kraj Goshforda, 100 kilometara sjeverno od Sydneya. Na zemljištu površine 22 jutra planirana je izgradnja Crkve Kraljice Hrvata, Dječji dom kardinal Stepinac i Dom hrvatskih časnih sestara. U idejnom rješenju središnjim dijelom kompleksa dominira crkva zvjezdastoga oblika posvećena Majci Božjoj, »u stilu naših prastarih Božjih hramova Dalmacije, da postane središnje hrvatsko hodočasničko mjesto: hram Kraljice Hrvata (Romac, 1959c, 14). Nasuprot crkve planiran je Hram hrvatskih žrtava, a bočno od crkve dvije zgrade, jedna za dječake i jedna za djevojčice, sa sobama za spavanje na katu i školskim prostorijama u prizemlju. Posebna zgrada predviđena je za hrvatske časne sestre, a na ostatku zemljišta bila bi uređena igrališta za djecu, šetnice i vrt. Školom bi upravljale hrvatske časne sestre, a namijenjena je za djecu hrvatskih iseljenika u vrijeme ljetovanja, ali i za djecu iz okolice tijekom cijele školske godine (Romac, 1961, 13).

Zvona namijenjena za buduću crkvu posvećena su u nedjelju 30. lipnja 1968., prilikom čega je fra Romac rekao: »Ja sam smatrao najprikladnijim da ova zvona posvetimo, jedno za sve Hrvate koji su pali za vjeru i domovinu, a drugo da se posveti svecima i blaženima, a koji su pripadali hrvatskom narodu « (Lovoković, 2010, 128). Zvona je blagoslovio fra Ambrose Ryan, prilikom čega je pohvalno izjavio kako se tijekom prošlogodišnje posjete Hrvatskoj i grobu kardinala mučenika Stepinca te Mostaru i Sarajevu »na vlastite oči uvjerio o vjerskim osjećajima hrvatskog naroda kod kuće« (Anon., 1968, 4).

\section{Optužbe za lažno predstavljanje}

Dolaskom u Australiju fra Romac je očekivao kako je našao potreban mir i slobodu u svojem vjerskom i svjetovnom djelovanju. Ipak, jugoslavenske vlasti, koje su ga progonile u Domovini i inozemstvu, svoje su protucrkveno djelovanje nastavile i na australskom tlu. U svibnju 1964. istaknuti član jugoslavenske zajednice Marjan Jurjević iznio je u melbournskim novinama Truth 16. svibnja 1964., u članku Ratni zločinac u Australiji, optužbe da je fra Roko Romac ratni zločinac te da je u Australiju ušao pod lažnim imenom. ${ }^{9}$ Navedene optužbe Jurjević je predočio Jimu Cairnsu, zastupniku opozicijske Radničke stranke i jednako gorljivomu protivniku hrvatske zajednice. Iznesene optužbe Jurjević je koristio za napade na hrvatsku zajednicu u Australiji, a Cairns je iste koristio kako bi vladajuću Liberalnu stranku osramotio i optužio za popustljiv odnos prema ekstremnoj hrvatskoj emigraciji. O iznesenim optužbama Jurjević je ispitan od strane policije 25. svibnja 1964. u prostorijama Jugoslavenske iseljeničke organizacije.

9 AU-NAA-A6937-PP/13. Romac, Stephan Roch, 1961-1986, str. 40. 
Jurjević je pritom iznio optužbe da je "australski" Roko Romac varalica te da je pravi Roko Romac poznat njegovoj obitelji iz predratnoga doba. Jurjević je izjavio da je pravoga Roka Romca upoznao tijekom ljeta 1938. ili 1939. za vrijeme trajanja festivala svetoga Roka u Lumbardi na Korčuli. Jurjević je naveo da je pravi Roko Romac ubijen tijekom kolovoza ili rujna 1941. u planinama iznad Sinja dok je vodio narod protiv Talijana. ${ }^{10}$

Jurjević je bio u pravu kada je rekao da "australski” Roko Romac nije pravi Roko Romac, međutim u nastavku svjedočenja Jurjević je saveznoj policiji, namjerno ili slučajno, iznio više pogrešnih tvrdnji, koje su "australskoga” Roka Romca u godinama koje su bile pred njim dovodile u više neugodnih situacija pred australskim vlastima i javnosti. Jurjević je netočno naveo da je pravi Roko Romac ubijen 1941. kod Sinja. Naime, pravi Roko Romac svećeničku službu obavljao je u Metkoviću od 1940. do 1944., kada je u strahu od partizanskih progona otišao u Zagreb. Pravi Romac već je sljedeće godine preko Austrije, gdje je kratko vodio skrb o hrvatskim izbjeglicama, otišao u Italiju, gdje je boravio do 1947., kada je otišao u SAD.

Jurjević je netočno naveo i kako bi “australski” fra Roko Romac mogao biti identičan s franjevcem imena Rafael Romac, ${ }^{11}$ koji je navodni ratni zločinac i koji je podrijetlom iz Metkovića. Fra Rafael Romac, kojega je kao ratnoga zločinca podrijetlom iz Metkovića spomenuo Jurjević, zapravo potječe iz Sinja i tijekom života brinuo je o više župa iz Dalmacije i Dalmatinske zagore. I fra Rafael Romac našao se je na meti partizana te je, kako bi izbjegao životnu opasnost, 1945. preko Zagreba i Austrije otišao u Italiju, gdje je boravio do 1948., kada je otišao u Argentinu. Jurjević je dakle u svojem svjedočenju policiji iznio niz pogrešnih tvrdnji povezujući tri životne sudbine u jednu zamršenu priču. Zapravo su sva trojica fratara (fra Osvald Toth, fra Roko Romac i fra Rafael Romac) u svojim životnim putevima imali sličnu sudbinu — u ratnim zbivanjima u Jugoslaviji neosnovano su od strane partizana optuženi za ratni zločin, na njih je pokušan atentat te su u strahu za vlastiti život preko Italije svoje svećeničko djelovanje nastavili u hrvatskim zajednicama u iseljeništvu, svaki na "svojem" kontinentu daleko od rodne zemlje. Jurjevićeve optužbe možemo promatrati kao dio šire politike Udbe na diskreditiranju hrvatske zajednice, posebno osoba koje su svojim radom doprinosile povezivanju i jačanju hrvatskih zajednica u Australiji i diljem svijeta. Upravo je takva osoba bio "fra Romac" Osvald Toth, »svjestan Hrvat, aktivno je djelovao protiv jugoslavenskog komunističkog režima i njegove politike, koja je

10 AU-NAA-A6119-2798. Roch Stephan Romac - Volume 1, 1964-1967, str. 26.

11 Fra Rafael Romac rođen je u mjestu Glavice kod Sinja, 11. kolovoza 1903. godine. Nakon završene Franjevačke gimnazije u Sinju 1920. pristupio je franjevačkoj Provinciji presvetoga otkupitelja u Zaostrogu. Pohađao je filozofski studij u Zaostrogu i teološki studij u Makarskoj. Bio je župnik u više mjesta Dalmacije i Dalmatinske zagore. U vrijeme Drugoga svjetskoga rata tijekom službe u Drveniku (1940.-1945.) partizani su ga pokušali ubiti, a spas je pronašao odlaskom u Zagreb. Napustio je Domovinu pred kraj Drugoga svjetskoga rata i preko Austrije otišao u Italiju. Italiju je napustio 1948. i svećeničko djelovanje nastavio u Argentini i Boliviji sve do smrti 1980. godine (Hoško, 1996, 174-184). 
nastojala da se uvuče u sve pore australskoga, pa i crkvenoga života, u čemu im je on bio nepremostiva zapreka« (Čovo, 2019, 192).

U obranu Osvalda Totha kao fra Roka Romca stali su vlč. Eris Tierney i provincijal franjevačkoga reda fra Ambrose Ryan, koji su potvrdili kako su upoznati s promjenom imena fra Roka Romca te kako je ono učinjeno iz sigurnosnih razloga. Fra Ambrose Ryan tijekom putovanja u Europi 1963. razgovarao je s fra Damjanom Damjanovićem, koji je potvrdio da je upoznat s promjenom imena i osobno ju je odobrio, uz dopuštenje i potvrdu generalnoga voditelja franjevačkoga reda u Rimu. Fra Ryan bio je upoznat is time da je rođeno ime fra Romca Stjepan Tot, da je rođen u Petrijancu 3. prosinca 1905., te da je promjena imena učinjena iz osobne sigurnosti kako bi fra Romac mogao početi novi život daleko od Titovih agenata. ${ }^{12}$

\section{Putovanje Europom}

Negativan publicitet koji se je u javnosti stvorio oko fra Romca i intenzivan rad u hrvatskoj zajednici rezultirali su njegovom velikom iscrpljenosti te se je na inicijativu franjevačkoga provincijala u Sydneyu odlučio na putovanje Europom kako bi stekao potreban mir i odmor. Australiju je napustio 5. svibnja 1965. te je posjetio Rim i Svetu Zemlju. Zajedno s fra Josipom Kasićem bio je primljen u audijenciju kod pape, o čemu su izvijestile novine Catolich advocate 25. lipnja 1965. godine. ${ }^{13}$ Posjetio je brata u Parizu, a za vrijeme boravka u Francuskoj obišao je Bordeaux i marjansko svetište Lourdes. Nakon Francuske otišao je u Španjolsku, odakle je posjetio marjansko svetište Fatimu. Posjet Fatimi opisao je u svojevrsnom putopisu u listu Hrvatski dom, gdje piše: »Teško da sam — osim moje prve svete Mise - pobožnije molio i povezao se sa sv. žrtvom oltara kao ovdje u Fatimi: molio sam i ćutio dužnost, da joj predam u ruke svu bijedu moga naroda, iz kojeg nikoh; sve čemere i jade Hrvata diljem svijeta, a najviše u domovini; svu hrabrost i žrtve naših mučenika i mučenica, koji su ustrajali u borbi očuvanja svoje vjere; sve žrtve mrtvih, koji su dali živote za domovinu, koja je poškropljena tolikim žrtvama u borbi protiv sotone; sve molitve naših majki, djece, mladića i djevojaka, koji su izdržali borbu sa sotonom kroz desetljeća i stvorili svetu vojsku za krst časni« (Romac, 1967, 8-9).

\section{Optužbe za političko djelovanje i terorističko organiziranje}

Optužbe koje je Jurjević iznio 1964. bile su ponovljene i sljedeće godine, uz dodatak kako je upravo fra Romac navodno organizirao članove hrvatske zajednice $u$ ilegalnu organizaciju Hrvatsko revolucionarno bratstvo $(\mathrm{HRB})^{14}$ te

12 AU-NAA-A6119-2798. Roch Stephan Romac - Volume 1, 1964-1967, str. 119-123.

13 AU-NAA-A6119-2798. Roch Stephan Romac- Volume 1, 1964-1967, str. 89.

14 Hrvatsko revolucionarno bratstvo (HRB) bila je tajna hrvatska iseljenička organizacija osnovana u Sydneyu 1961. godine. Revolucionarnim metodama željela je izazvati nestabilnost i rušenje 
da im je omogućio održavanje sastanka i vježbanje upravljanja radio stanicom u knjižnici Hrvatskoga katoličkoga centra u Sydneyu. Fra Romac je o navedenim optužbama ispitan od strane policije u prisutnosti vlč. Erisa Tierneya, voditelja Katoličkoga ureda za emigraciju. U razgovoru je policiji potvrdio kako je čuo za optužbe da su u knjižnici koju vodi održavani sastanci HRB-a te je izjavio kako je moguće da se navedeni sastanak održao, ali kako on to ne može ni potvrditi ni negirati s obzirom na to da u navedenim prostorijama ne stanuje, nego se svakoga poslijepodneva vraća u kuću u kojoj boravi u Victoria Street Waverley. ${ }^{15}$

Fra Romčeve navode potvrđuje i izvješće australske tajne službe (ASIO) od 25. lipnja 1964., u kojem stoji kako Roko Romac definitivno nije imao saznanja da se devetorica uhićenih pripremaju za upad u Jugoslaviju ${ }^{16}$ te da bi ih spriječio u odlasku, pa makar to značilo i da ih prijavi policiji. ${ }^{17}$

Australska policija tijekom 1960-ih provela je više pretresa stanova hrvatskih iseljenika u potrazi za ekstremnim (terorističkim) aktivnostima, na što su ih stalno upozoravale jugoslavenske vlasti, često neutemeljeno i bez relevantnih dokaza, s ciljem ocrnjivanja hrvatske zajednice pred australskom vlasti i javnosti. Dokumenti zaplijenjeni tijekom pretresa stanova članova HRB-a (Jure Marića, Rudolfa Franjića i Viktora Kupera) od 3. ožujka 1967. ne sadrže nikakve materijale koji bi fra Romca doveli u vezu sa sudjelovanjem u radu HRB-a. ${ }^{18} \mathrm{U}$ pismima zaplijenjenima pojedinim članovima HRB-a u međusobnoj korespondenciji fra Romac se navodi pod svojim punim imenom i prezimenom (ili prema inicijalima R. R.), što ga također isključuje kao člana HRB-a jer su se u međusobnim dopisivanjima svi članovi HRB-a koristili kodnim imenima u obliku rednih brojeva. U jednom od zaplijenjenih materijala tako se navodi kako je glavni odgovorni za knjižnicu Hrvatskoga katoličkoga centra član HRB-a pod rednim brojem 161 te kako on ima ključeve i odgovoran je za održavanje poduka. U kasnijim međusobnim dopisivanjima članova HRB-a stoji i kako prostor knjižnice ne odgovara uvjetima potrebnima za održavanje poduke te kako će biti potrebno unajmiti ili pronaći neki bolji prostor za potrebe pripremanja. ${ }^{19}$

U obranu fra Romca stao je voditelj Katoličkoga ureda za emigraciju vlč. Eris Tierney. Upravo je njegov ured uputio fra Romca u svibnju 1957. u Sydney da vodi brigu o tamošnjoj hrvatskoj zajednici, a tijekom cijeloga vremena djelovanja s fra Romcem ured je redovito komunicirao i surađivao. Velečasni Tierney odbacio je svaku mogućnost da je fra Romac organizirao i poticao političke i revolucionarne sastanke i cijenio ga je kao osobu snažnoga karaktera, velike hra-

Jugoslavije s ciljem stvaranja samostalne i neovisne hrvatske države. Organizirala je nekoliko upada u Jugoslaviju, od kojih su najpoznatije Akcija Tolić-Oblak iz 1963. i Bugojanska akcija iz 1972. godine.

15 AU-NAA-A6119-2798. Roch Stephan Romac - Volume 1, 1964-1967, str. 123-127.

16 Izvješće o upadu hrvatskih emigranata, članova HRB-a, u Jugoslaviju u Akciji Tolić-Oblak 1963. godine.

17 AU-NAA-A6119-2798. Roch Stephan Romac - Volume 1, 1964-1967, str. 21.

18 AU-NAA-A6119-2799. Roch Stephan Romac - Volume 2, 1967-1970, str. 85.

19 AU-NAA-A6119-2799. Roch Stephan Romac - Volume 2, 1967-1970, str. 20. 
brosti i čvrstih kršćanskih uvjerenja. ${ }^{20} \mathrm{U}$ obranu fra Romca stao je i franjevački provincijal savezne države New South Wales, koji je optužbe za tajno političko djelovanje i organiziranje terorističkoga centra odbacio kao neistinite i krajnje djetinjaste. Fra Ambrose Ryan odbacio je i optužbe o uključivanju fra Romca bilo u kakve političke aktivnosti među hrvatskom zajednicom u Australiji. Naglasio je fra Romčevu vjernost svećeničkomu pozivu, na čiji rad nije bilo nikakvih pritužbi, i naglasio kako su crkveni velikodostojnici iz sydneyske nadbiskupije u potpunosti zadovoljni njegovim radom. ${ }^{21}$

Službene australske vlasti nakon ispitivanja fra Romca nisu poduzimale daljnje korake u vidu novih ispitivanja niti su protiv njega podnijele optužnicu bilo za koje djelo iz optužbi koje su mu jugoslavenske strukture stavljale na teret. Australska tajna policija, kojoj je jedan od najvažnijih zadataka sprječavanje terorističkih aktivnosti, 1965. navela je kako nema potrebe za daljnjim ispitivanjem fra Romca s obzirom na to da je to već učinila Savezna policija (Commonwealth Police) i posebni odjel policije države New South Wales. ${ }^{22}$

\section{Prerani odlazak}

Fra Roko Romac preminuo je 15. ožujka 1970. u 65. godini života nakon kraće bolesti. Sprovodu je prisustvovao primas Australije i nadbiskup Sydneya kardinal Norman Gilroy, direktor Katoličkoga ureda za emigraciju mons. George Crennan, vlč. Eris Tierney, fra Ryan i mnogi drugi franjevci. Svetu misu u crkvi sv. Antuna Padovanskoga na Summer Hillu služio je fra Lambert Ivančić uz asistenciju fra Ivana Mihalica i fra Josipa Kasića, braće franjevaca, koji su i najviše sudjelovali u njegovu vjerničkom životu. Crkva svetoga Antuna Padovanskoga, čiju je kupnju fra Romac inicirao i proveo, bila je potpuno ispunjena. »Sprovod je bio tako svečan i velik, da se činilo kao da je umro neki visoki crkveni prelat [...] Tužna povorka od nekoliko stotina automobila u duljini od $2-3$ milje zaustavila je gotovo sav promet u ovom sydneyskom predjelu na putu prema groblju u Rookwood-u« (Maglica, 1970, 9).

Biranim riječima od fra Romca oprostio se je Milan Maglica, dugogodišnji suradnik u novinama Dom: »Čovjek s takvim duševnim i tjelesnim sposobnostima i talentima i širokom kulturom imao je neki unutrašnji osjećaj sigurnosti u svoje podhvate i planove, koje je uvijek polagao u ruke svoga Stvoritelja. Kao gorljivi štovatelj Gospe i širitelj kulta kard. Stepinca znao je ovaj postojani sin sv. Franje prenositi kršćansku ljubav i razumijevanje među svoje povjereno stado« (Maglica, 1970, 9).

Odlazak fra Roka Romca ostavio je u hrvatskoj zajednici u Australiji veliku prazninu i jednako neizbrisivu uspomenu o marljivom i vjernom pastiru koji je svoje stado držao na okupu unatoč svim životnim nedaćama koje su ga snalazile,

20 AU-NAA-A6119-2798. Roch Stephan Romac - Volume 1, 1964-1967, str. 117.

21 AU-NAA-A6119-2798. Roch Stephan Romac - Volume 1, 1964-1967, str. 120.

22 AU-NAA-A6119-2798. Roch Stephan Romac-Volume 1, 1964-1967, str. 130. 
ali istovremeno davale vjeru i snagu da svojim primjerom pokaže put koji treba slijediti i živjeti.

\section{Zaključak}

Život i djelo fra Osvalda Totha, odnosno Roka Romca bili su obilježeni brojnim izazovima i stalnom neizvjesnosti. Vlada Kraljevine Jugoslavije zabranila je njegove crkvene aktivnosti, partizani su ga pokušali ubiti za vrijeme Drugoga svjetskoga rata, a poslijeratne jugoslavenske vlasti stavile su ga na popis traženih ratnih zločinaca. U Domovini je djelovao u Banovini, na prostoru s mješovitim hrvatskim katoličkim i srpskim pravoslavnim stanovništvom, u Njemačkoj među Hrvatima koji su služili na prisilnom radu, a u Italiji u izbjegličkim kampovima. U strahu od izručenja Jugoslaviji i izravne smrtne opasnosti promijenio je ime i otišao daleko od kuće, preko Argentine do Australije. Najveći trag ostavio je među Hrvatima Sydneya i okolice, gdje je najduže i služio, od 1957. do 1970. godine. Pokrenuo je i uređivao novine Dom, prvi vjerski mjesečnik Hrvata u Australiji. Inicirao je kupnju prve hrvatske katoličke crkve u Australiji posvećene sv. Antunu Padovanskomu. Veliku važnost posvećivao je mladima, posebno njihovu obrazovanju, a u mjestu Tumbi Umbi pokrenuo je veliki projekt izgradnje škole i svetišta posvećenoga Majci Božjoj. Upravo je u hodočašću marijanskim svetištima pronašao snagu i utočište od jugoslavenskih optužbi pred australskim vlastima. Važnu ulogu u njegovu životu imao je i blaženi Alojzije Stepinac, koji mu je služio kao uzor optuženih i progonjenih, a ipak jednako nepokolebljivih u očuvanju i širenju kršćanskoga duha i nacionalnih vrijednosti.

\section{Literatura}

Anon. (1968). Blagoslov zvona u Tumbi. Hrvatski dom: Glasnik Hrvata Australije, Oceanije $i$ Nove Zelandije, 11(7/8), 3-4.

Čovo, Stjepan (2019). Franjevci izbjeglice Franjevačke provincije Presvetoga Otkupitelja. Split: Franjevačka provincija Presvetoga Otkupitelja.

Hoško, Franjo Emanuel (1996). Franjevci među Hrvatima u Sydneyu: Povijest dušobrižništva 1957.-1994. Summer Hill: Hrvatski katolički centar.

Kasić, Josip (1962). Na početku našeg petog godišta. Hrvatski dom: Glasnik Hrvata Australije, Oceanije i Nove Zelandije, 5(1), 3-4.

Lovoković, Fabijan (2010). Hrvatske zajednice u Australiji: Nastojanja i postignuća. Kingsgrove: Središnji odbor hrvatskih društava Australije.

Maglica, Milan (1970). O. Roko Romac-Toth, ofm. Hrvatski dom: Glasnik Hrvata Australije, Oceanije i Nove Zelandije, 13(4), 8-9.

Romac, Roko (1958). Urednik govori. Dom: Mjesečnik za vjersko-kulturni život Hrvata u Australiji i Oceaniji, 1(1), 13-14.

Romac, Roko (1959a). C.W.A. Croatian welfare association - Sydney. Dom: Mjesečnik za vjersko-kulturni život Hrvata u Australiji i Oceaniji, 1(12), 14.

Romac, Roko (1959b). C.W.A. Croatian welfare association — Sydney. Dom: Mjesečnik za vjersko-kulturni život Hrvata u Australiji i Oceaniji, 2(1), 15. 
Romac, Roko (1959c). Cesta smrti: Sydney — Gosford. Dom: Mjesečnik za vjersko-kulturni život Hrvata u Australiji i Oceaniji, 2(6), 13-14.

Romac, Roko (1961). Tumbi-Umbi. Dom: Mjesečnik za vjersko-kulturni život Hrvata u Australiji i Oceaniji, 4(3), 12-13.

Romac, Roko (1967). Svjetlost iz Fatime. Hrvatski dom: Glasnik Hrvata Australije, Oceanije i Nove Zelandije, 10(7-8), 7-9.

Arhivsko gradivo

AU-NAA. National Archives of Australia

AU-NAA-A6119-2798. Roch Stephan Romac - Volume 1, 1964-1967.

AU-NAA-A6119-2799. Roch Stephan Romac - Volume 2, 1967-1970.

AU-NAA-A6937-PP/13. Romac, Stephan Roch, 1961-1986.

Friar Roko Romac, Spiritual Father of Croats in Australia (1955 - 1970)

Ante Kožul*

Summary

The life and work of Friar Osvald Toth/Roko Romac were marked by numerous challenges and constant uncertainty. His ecclesiastical activities were banned by the government of the Kingdom of Yugoslavia; the Partisans tried to kill him during WWII, while the post-war Yugoslav authorities put him on the list of wanted war criminals. He ministered as a priest in the Banovina region which had a mixed Croatian Catholic and Serbian Orthodox population, then in Germany among Croats who were used as forced labor and also in the refugee camps of Italy. Fearing extradition to Yugoslavia and being in imminent danger of death, he changed his name and went far from his homeland, via Argentina to Australia. He left his greatest mark among the Croats of Sydney and the surrounding area, where he served for the longest period of time, namely from 1957 to 1970. There he launched and edited the newspaper, "Dom", the first monthly religious newspaper of the Croats in Australia; he initiated the purchase of the first Croatian Catholic Church in Australia and dedicated it to St. Anthony of Padua; he placed a great importance on young people, especially their education; in Tumbi Umbi he started a big construction project for a school and sanctuary dedicated to the Mother of God. It was during his pilgrimages to Marian shrines that he found strength and refuge from Yugoslav accusations before Australian authorities. Blessed Alojzije Stepinac played an important role in his life and served as a role model for those unjustly accused and persecuted, yet steadfast in preserving and spreading the Christian spirit and national values.

Key words: Roko Romac; Osvald Toth; Stjepan Tot; newspaper "Dom"; Croatian emigrants; Croatian Catholic Center Summer Hill; Tumbi Umbi

* Ante Kožul, Doktorand, Department of History, Faculty of Croatian Studies, University of Zagreb. Address: Borongajska cesta 83d, 10000 Zagreb, Croatia. E-mail: antekozul@gmail.com 